\title{
State Regulation of Hazards Growing Out of the Use of Atomic Energy
}

\author{
Albert W. Harris, Jr.*
}

The emergence of a peacetime atomic energy industry in the United States has thrust upon state governments a host of problems involving public health and safety. Literally thousands of industrial and medical uses of radioisotopes have been developed. ${ }^{1}$ Yet the occupational safety laws of many states have not been brought up to date to insure the safety of workers exposed to these radioactive materials. Nuclear reactors are spotted from place to place throughout the nation, primarily for research purposes but mcreasingly for power production. ${ }^{2}$ These reactors produce large quantities of highly radioactive waste materials which must be disposed of in one way or another. ${ }^{3}$ Few states at present stand ready to insure safety in the handling and transportation of these wastes and to require metliods that will prevent long-term harmful effects to public health and natural resources. In addition, new businesses have developed and function under a regulatory system wholly unsuited to the special problems of ionizing radiation. For example, the California law regulating laundries is of little or no relevance to a new laundry near San Francisco which is devoted exclusively to cleaning the radioactive work garments of employees of a radiation laboratory. ${ }^{4}$

These problems require not only long-range planning but immediate decisions. However, before any decisions can be reaclied, some hard and basic questions must be answered: (1) Can the states formulate standards for the prevention of hazards growing out of atomic energy activities, particularly with reference to AEC licensees? If so, must these standards be the same as those promulgated by the AEC, or can those standards be varied or supplemented? (2) Is the state government organized in such a fashion that health and safety standards can rationally be formulated with-

* Deputy Attorney General of California, San Francisco.

The author wishes to express his appreciation for the encouragement and assistance of Attorney General Edmund G. Brown and Assistant Attorney General Henry A. Dietz. The opinions expressed in this article are, of course, personal to the author.

1 See remarks of AEC Commissioner Willard F. Libby, AEC Press Release, May 13, 1957, pp. 2-20.

2 See paper prepared by Davis and Roddis, Director and Deputy Director respectively of AEC Division of Reactor Development, AEC Press Release, March 14, 1957.

${ }^{3}$ Enough fission products are produced in one year by a reactor of $60,000 \mathrm{kw}$. capacity to contaminate to the limits of tolerance an area twenty-five miles on a side to a height of onehalf mile. McCuliovoH, Milis \& Telzer, The Safety of Nuclear Reactors 4 (1955).

\& San Francisco Chronicle, Sept. 30, 1957, p. 6, col. 3. 
out overlapping of jurisdiction and a multiplicity of regulations? Should a "little AEC" be created? Or should the action of many agencies be coordinated? (3) Given standards and an effective state administrative structure, what techniques of enforcement should be used? Can a state require licenses from radiation sources? Should sources be registered? Is an adequate inspection system feasible economically or workable administratively? What sanctions can be imposed for violations?

Intertwined in these questions are problems involving the constitutional spheres of authority of the state and federal governments, the construction of federal and state laws and regulations, and the expediency and practicality of technological and administrative programs. This paper is not an attempt to answer these questions; it is an attempt to highlight some of the problems, to indicate the course of state action, and to suggest a few alternatives.

\section{I}

THE FORMULATION OF STANDARDS

The use of the term "atomic energy" tends to connote the use of nuclear reactors, particularly for power, and radioisotopes for inedical, research and commercial uses. It is, of course, precisely these inatters that pose the problenı we are concerned with. However, it is the quality of iomzing radiation growing out of those activities which is of primary importance from the health and safety standpoint. ${ }^{5}$ Probably the most common source of such radiation is from the thousands of X-ray machines in medical and industrial use. There may be many questions as to how $\mathrm{X}$-ray machines should be controlled; there is no question that the control is vested in the states. Similarly, the states have complete authority over naturally occurring radioactive material, such as radium, and radioisotopes not distributed by the AEC. The questionable area of state jurisdiction is with respect to radiation sources licensed by the AEC.

It seems curious to suggest that a state has no authority over the disposal of radioactive wastes in the sea involving effects with respect to health on the shores of the state and associated effects on wildlife. Similarly, it is hard to believe that a state is without control over the proposed storage of wastes in an abandoned mine shaft within its territorial hmits, a plan proposed near the San Francisco Bay Area. Yet under the Atomic Energy Act of $1954^{7}$ serious questions of state jurisdiction are presented. By that act

6 "[T] $]$ he body suffers similarly whatever the source of the radiation." NATIONAI BUREAU of Standards Handbook 61, Regulation of Radiation Exposure BY Legisiative Means 20 (1955).

B See AEC Press Release No. 687, Aug. 30, 1955, announcing termination of distribution of cyclotron-produced radioisotopes by $\mathrm{AEC}$.

768 Srat. 919, as amended, 42 U.S.C. \$\$ 2011-281 (Supp. IV 1956), as amended, 71 STaT. 576, 14 U.S. CoDe CoNG. AND ADMr. NEws 2925 (1957). 
the AEC was authorized to impose health and safety standards on licensees, ${ }^{8}$ and such regulations have been issued. ${ }^{\circ}$ Nowhere in the act is there any indication of the role of the states..$^{10}$ This, of course, has raised many questions: Is there any constitutional basis for this exercise of federal power?" Has the federal government "occupied the field?" Or part of the field, and, if so, what part? Or have the states concurrent jurisdiction to regulate?

Despite this uncertainty, there has been a considerable amount of state action in formulating health and safety standards. Most of the attention has been focused on the safety of workers who handle radioactive materials or may be exposed to sources of radiation on the job. Several states prescribe some limitation on radiation exposure in places of employment. ${ }^{12}$ In California ${ }^{13}$ and New York, ${ }^{14}$ detailed industrial safety regulations have been adopted. Less attention has been devoted to the protection of the public. The New York Sanitary Code supplements the state industrial safety regulations and prescribes standards for, among other things, protection of patients from $\mathrm{X}$-ray equipment, methods of radioactive waste disposal, and safety in the use of shoe-fitting fluoroscopes. ${ }^{15} \mathrm{~A}$ California statute prohibits the hazardous disposal of radioactive wastes. ${ }^{16}$ Both Pennsylvania and Texas have adopted the suggested regulations of the National Committee on Radiation Protection, which apply to all sources of radiation and are designed for public, as well as employee, protection. ${ }^{17}$ Several

8 The act requires hicenses of persons who possess or use source material, special nuclear material or byproduct material (Atomic Energy Act of 1954, $\$$ 53, 63, 81, 68 STATs. 930, 933, 935, 42 U.S.C. $\$ \$ 2073,2093,2111$ (Supp. IV 1956)), or possess facilities for the production or utilization of special nuclear material (Atomic Energy Act of 1954, §§ 103, 104, 68 STAT. 936, 937, as amended, 42 U.S.C. \$§ 2133, 2134 (Supp. IV 1956)). Licenses are conditioned on compliance with AEC regulations (Atomic Energy Act of 1954, §§ 103b, 104b, c, 68 STAT. 936, 937, as amended, 42 U.S.C. $\$ \S 2133$ (b), 2134 (b) (c) (Supp. IV 1956)). Health and safety regulations may be issued by the AEC (Atomic Energy Act of 1954, §§ 161b, i(3), 68 STAT. 948, 949 (1954), as amended, 42 U.S.C. \&2201(b), (i) (3) (Supp. IV 1956)).

922 FED. REg. 548-54 (1957).

10 The regulation of rates by state utility commissions is preserved by the act. Atomic Energy Act of 1954, § 271, 68 STat. 960, 42 U.S.C. § 2018 (Supp. IV 1956).

11 See Estep, Federal Control of Health and Safety Standards in Peacetime Private Atomic Energy Activities, 52 MrCH. L. REv. 333 (1954).

12 For a summary of occupational safety regulations for the following states, see ATOMnc Industriat, Forom, INC., State Activities IN Atomic Energy 4 (Arkansas), 6 (Colorado, Connecticut), 7 (Florida), 9 (Kentucky), 10 (Oregon), 18 (West Virginia), 19 (Wisconsin) (Feb. 1, 1957).

138 Cat. Admotn. Code $\$ \$ 3800-13,3860-61$.

14 N.Y. Industrial Cgde, Rule No. 38.

15 N.Y. SantTaRY CODE, c. XVI.

10 CaLtF. Healte \& SafeTy Code $\$$ 25600-04.

17 Penn. Dep't of Heatte Reg. 433 ; Texas Dep't ge Health Regulatign on Radiatign EXPOSURE; for the suggested regulations of the NCRP, see National BuREaU OF STANDARDS Handbgok 61, Regutation of RAdiatign Exposure by Legislative Means 36 et seq. (1955). 
states have recently authorized agencies to adopt public safety regulations ${ }^{18}$ or have, by statute, required safety in radiation operations. ${ }^{19}$

Little or no attempt has been made to assess the validity of these standards as applied to AEC licensees, probably because of the likelihood of action by Congress to define the respective spheres of jurisdiction of the state and federal governments. Representatives of the AEC have taken pubhicly a moderate approach toward this problem, emplrasizing federalstate cooperation rather than federal supremacy. ${ }^{20}$ State officials, wlile occasionally somewliat restive, have been hesitant to take a strong "state's rights" position in this relatively unknown area. In fact, the only substantive provision in the New England Model Act insures the validity of AEC licenses as to wholly intrastate operations. ${ }^{21}$

Various bills were introduced in Congress to clarify the extent of state power, ${ }^{22}$ and the bill sponsored by the AEC is discussed elsewhere. ${ }^{23}$ However, even this latter amendment will leave a great many questions unanswered.

The amendment provides generally that nothing in the act shall be deemed to prevent states from adopting standards "not in conflict with those adopted by the Commission." This is understandable with respect to such measurable matters as maximum permissible doses of radiation. ${ }^{24}$ However, it is not so clear with respect to the kind of regulation that calls for periodic ad hoc determinations of specific factual problems. This is best characterized by the problem of the disposal of radioactive wastes. The present AEC regulations prescribe standards for certain methods of dis-

18 Coro. Rev. Stat. \$ 66-1-7 (1953), as amended by H.B. No. 104 (effective March 13, 1957), Colo. Sess. Laws, c. 156 (1957) ; Conn. Pub. Act No. 154, Acts of 1957 (effective May 11, 1957); Laws of N.D. 1957, c. 185 (effective July 1, 1957); Ore. Laws of 1957, c. 399 (effective July 1, 1957); Sess. Laws of S.D., c. 122 (effective March 18, 1957).

10 N.J. Pub. Health Laws, c. VI.

20 An Advisory Committee of State Officials has been created by the AEC to give the states a voice in the Commission. AEC News Release, No. 735, Nov, 25, 1955. The proposed AEC Radiation Safety Regulations were twice submitted to this advisory committee. AEC News Release, No. 969, Jan. 25, 1957.

21 The Report of tere New England Concmittee on Atomic Energy to tere New Engiand Governors' Conference, Atonitc Energy and New England 64 (1955).

22 H.R. 8676, 84th Cong., 2d Sess. (1956) (to transfer health and safety responsibilities to the states whenever governor decides state is competent) ; S. 4298, 84th Cong., 2d Sess. (1956); S. 53, 85th Cong., 1st Sess. (1957) (to authorize AEC to cooperate with states and develop agreements to turn over regulatory powers to states AEC determines are competent). See remarks of Senator Anderson, Council of State Governments, Conference on the States AND Atonifc Developarent 16-22 (May 10-11, 1957).

23 See text at notes $28,50,65$, and 80 infra; Cavers, Legislative Readjustments in Federal and State Regulatory Powers Over Atomic Energy, elsewhere in this issue.

24 Compare \$ 20.101, 22 FED. REg. 550 (1957), with N.Y. SANTTARY Code, c. XVI, reg. 4 and 8 CAL. ADMmN. CODE $\S 3803$ (AEC, New York and California maximum permissible doses or exposures of radiation). 
posal ${ }^{25}$ however, it is further provided that any proposal not covered by the prescribed standards will be submitted to the AEC for decision. ${ }^{26}$ This approach to waste disposal seems necessary under present conditions. The National Committee on Radiation Protection observes in the note to its own proposed waste disposal regulation: ${ }^{2 \pi}$

It is impractical or impossible at the present time to formulate detailed waste-disposal regulations that will provide adequate safety under all conditions without being unnecessarily restrictive under most conditions. Not only do the relevant factors vary with each locality, but virtually every radioisotope presents a different problem. A few broad rules applicable to cases of most common interest can be stated, but im general the procedures must be adjusted ... to take into account the particular circumstances involved.

While a flexible approach may be useful, it is difficult to reconcile this fiexibility with concurrent state and federal jurisdiction. The requirement, for example, that any proposed plan be submitted to a state agency smacks of "licensing," which is forbidden by the proposed amendment. ${ }^{28}$

Another problem arises from the power of the AEC to grant exemption from its regulations in specific instances ${ }^{29}$ and from the specific exemption of certain matters in the regulations. For example, sewage with a radioactive content is discharged from hospitals using radioactive iodine and other isotopes. This type of waste disposal is exempted from compliance with AEC safety regulations. ${ }^{39}$ Does this preclude a state from imposing safety standards on sewage of this kind even though its officials believe, rightly or wrongly, that such standards are necessary?

\section{III}

\section{ADMINISTRATIVE ORGANTZATION}

While the scope of state power over standards seems to await congressional action, the states are free to reorganize their administrative framework as they please to deal with problems of the atomic era. State governmental structure is normally defined in terms of the objects of health and safety hazards, rather than the type of hazard. The safety of workers in

25 Concentrations of radioactive materials released into air or water, $\$ 20.103,22$ FED. REO. 551 (1957) ; disposal into sanitary sewage systems, § 20.303, 22 FED. REO. 552 (1957); disposal by burial in soil, $\S 20.304,22$ FED. REG. 553 (1957).

$26 \S 20.302,22$ FED. REg. 552 (1957).

27 Nationat Buread of Standards Handbook 61, Regulation of Radiation Exxosure by Legislative Means 49 (1955).

28 AEC Proposed Amendment to Atonac Enercy Act or 1954, § 274(b) (1957).

20 "The Commission may ... grant such exemptions from the requirements of the regulations in this part as it determines are authorized by law and will not result in undue hazard to life or property." § 20.501, 22 FED. REG. 553 (1957).

80 \& 20.303, 22 FED. REG. 552 (1957). 
places of employment may be delegated to one agency. Many aspects of public protection from health hazards may be given to a department of health, with jurisdiction over certain objects of hazards, such as air and water pollution, granted to separate agencies. Utility commissions sometimes have health and safety regulatory power. An agency is often established to preserve wildlife. Each agency then may be concerned with a different facet of atomic energy activities. For example, in Califorma, the disposal of radioactive wastes into the sea or rivers will concern many state agencies, including the departments of Industrial Relations, Public Health, Fish and Game, Water Resources, the State Water Pollution Board, and perhaps others. Counties, cities, zoning and planning boards, and other local agencies may have related interests. Many state agencies are relatively unfamiliar with radiation hazards and ill-equipped in terms of personnel and experience to adopt and enforce unilaterally standards for protection. Yet the need for uniformity and consistency of standards, together with enforcement practice, is of vast importance, with respect to intrastate relations, federal-state cooperation and possible multistate action. ${ }^{31}$

In its report to the New England Governors' Conference, the New England Committee on Atomic Energy prepared a model bill designed to place the states in a position to deal with the problems associated with atomic energy..$^{32}$ The key to the bill is in the establishment of a state office of Coordinator of Atomic Development Activities. Each state agency is directed to study its own responsibilities and recommend such legislation or regulation as is necessary. All such recommended action is to be submitted to the coordinator prior to adoption and thus the state's action on atomic energy will be centralized. From an administrative standpoint, each agency will retain its traditional jurisdiction-over occupational safety, public health, etc.-yet a mechanism is built-in to eliminate conflicting standards and insure that a uniform policy results. This bill will bring within a framework of coordination all facets of the problems growing out of atomic energy, such as workmen's compensation, insurance and public utility regulation, as well as health and safety control. Since the relationship between the federal and state governments is still uncertain and the states step rather uneasily in this new area of regulation, the office of coordinator provides a ready means of communication with the federal government. The

81 For a detailed discussion of the impact of atomic energy in California, see Dietz and Harris, How Shall California Government Meet the Challenge of Atomic Energy, 8 Hastrigs L.J. 119 (1957); see also Krebs and Hamilton, The Role of the States in Atomic Development, 21 Law \& Contearp. Prob. 182 (1956).

32 The Refort of the New England Comanttee on Atoma Energy to tere New EnglaAnd Governors' Conference, Atomac Energy and New England 63-68 (1955). See also Krebs and Hamilton, The Role of the States in Atomic Development, 21 LAw \& Contemp. PROB. 182, 204-10 (1956). 
AEC has indicated its approval of a central state office with which it can deal..$^{93}$ In addition, the probable multistate effects of atomic energy activities require that each state be in a position to deal effectively with other states.

In 1955, Connecticut, Maine, New Hampshire and Rhode Island adopted in substance the provisions of the model bill. ${ }^{34}$ Massachusetts followed in 1956, adding a "Massachusetts Commission on Atomic Energy." South Carolina adopted in substance the model bill, however, without a coordinator. ${ }^{36}$ In 1957, Arkansas, Florida, Ohio, Tennessee and Washington enacted the proposed bill. ${ }^{37}$ Georgia created a "Nuclear Advisory Commission" which appears to follow much the same approach as the New England Bill. ${ }^{38}$ Thus, at present, twelve states have followed the lead of New England, primarily in New England and the South, with one state each in the Middle West and Far West. In California, the substance of the New England Bill was introduced in the state legislature in 1957 but failed to become law. ${ }^{30}$

Another approach has been suggested by the National Committee on Radiation Protection. This is an advisory body to the National Bureau of Standards whose recommendations on radiation exposure are widely followed and highly respected. This group reversed its previous stand in opposition to radiation protection legislation in 1955 and published a "Suggested State Radiation-Protection Act." ${ }^{\prime 40}$ This act would create a new agency in state government, a radiation-control agency, or integrate such a body into an existing agency. At any rate, the agency would be granted broad rulemaking power in order to control the hazards associated with radiation, including waste disposal, exposure limits, the adequacy of design of radiation sources, and the making of inspections.

In contrast to the New England Bill, this proposed act would be limited to the problem of radiation protection, rather than including other problems of atomic energy, and it would create a new agency with jurisdiction

\footnotetext{
${ }^{33}$ See remarks of Curtis A. Nelson, Director of the AEC Division of Inspections, AEC Press Release, Feb. 2, 1957.

34 Conn. Gen. Stat. c. 162e, § 1932d (1955); Me. Rev. Stat. c. 52-A, §8 1-6 (1955); N.H. REv. Stat. c. 162-B (1955) ; R.I. Gen. Laws \$ 42.27-1 (1956).

85 Mass. ANN. Laws c. 6, \$§ 85-93 (Supp. 1957).

${ }^{86}$ S.C. Acts 1956 No. 819 (Mar. 31, 1956).

37 ARr. Stat. ANN. § 82-1401-06 (Supp. 1957); Gen. Laws of Fla. 1957, S.B. No. 418 (July 23, 1957); O\#ro Rev. CODE $\$ \S 4163.01-.06$ (1957); Public Acts of Tenn. 1957, c. 324 (Mar. 23, 1957) ; Wash. Laws 1957, c. 92 (Mar. 13, 1957).

38 Ga. Laws 1957, c. 17 (Feb. 15, 1957).

${ }^{30}$ Cal. Legis. A.B. 975, S.B. 2625 (1957).

40 National Bureau of Standards Handbook 61, Regulation of Radiation Exposurg BX LegistattVe Mrans 27-35 (1955).
} 
either carved out of, or overlapping with, many other agencies. In Califormia, for example, the creation of such a new agency would cause jurisdictional problems affecting the Department of Public Health, the Department of Industrial Relations, the State Water Pollution Control Board, the Department of Fish and Game, Regional Air Pollution Control Boards, to name only a few. Only one state, thus far, has adopted the NCRP proposal -South Dakota. ${ }^{11}$ Careful study of the administrative and organizational repercussions of this legislation will be required before it is enacted elsewhere.

Some of the states have not enacted general or special legislation, beyond authorizing existing agencies to act with respect to radiation hazards within their normal jurisdiction. New York has extensive regulations without benefit, apparently, of state-wide coordmation or special agencies: Department of Health regulations in the Sanitary Code; ${ }^{42}$ the State Industrial Code with respect to places of employment; ${ }^{43}$ the draft of a state building code; New York Port Authority regulations covering transportation through tunnels; and proposed regulations by New York City. ${ }^{44}$ Pennsylvania and Texas have clothed existing agencies with extensive rulemaking powers. ${ }^{45}$

The pattern over the United States, then, varies from an attempt to act through established agencies retaining traditional jurisdictional limits with state-wide coordination at the top level of government, to the creation of a wholly new specialized agency or the delegation to an existing agency of broad jurisdiction over radiation hazards, with some states incorporating radiation protection into existing agencies with no overall coordinating mechanism.

Another facet of state organization, and one which has received little attention, is the integration of local governmental units, such as cities, counties and various kinds of districts, into the state policy on atomic energy. Primary authority over zoning laws, pertinent to the location of reactors, for exaunple, is normally the business of local government. Very often local health officers have considerable authority over public health hazards. ${ }^{40}$ Air and water pollution control is sometimes vested in county and regional

41. S.D. Sess. Laws of 1957, c. 122 (Mar. 18, 1957).

42 See note 15 supro.

48 See note 14 supra.

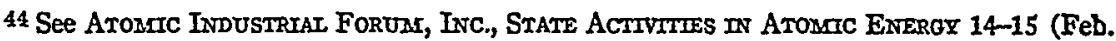
1, 1957).

45 Note 17 supra.

46 Under the New York health regulations, radiation installations must register with local health officers. N.Y. SANTTARY CODE, c. XVI, reg. 2. 
boards. ${ }^{47}$ It would be useful to bring local agencies within the orbit of state-wide coordination to achieve a rational and consistent state policy on atomic energy.

While local units are important, there are also significant multistate effects from atomic energy activities. Air-borne concentrations of radioactive materials and contaminated river waters have no respect for state boundaries. It may be necessary for effective state control to develop plans for regional action. The New England Bill, since it developed at a conference of New England governors, is itself a reflection of this necessity. ${ }^{48}$ The Southwestern Legal Foundation has already started work on analyzing the possibilities of interstate coordination, including compacts, at the request of the Southern Governors' Conference. ${ }^{49}$

Whatever means a state might choose to meet the challenge of atomic energy, it appears obvious that some special organization will be required in all states to meet the necessities of the atomic era both with respect to the formulation of health and safety standards and the enforcement of such standards.

\section{III}

\section{TECHNIQUES OF ENFORCEMENT}

However standards for protection may be formulated, whether by the states, the federal government or both, and however the state may wish to organize or reorganize its administrative structure, there are at least three requisites for the enforcement of health and safety laws. First, the state must be aware of what is happening within the state-that is, what are the sources of radiation? Secondly, the state must establish a system of inspection to insure that radiation sources are safely operated. Finally, effective sanctions must be available to prevent and punish non-compliance with safety standards.

\section{A. Registration}

The most effective way of apprising the state of any activity is to require state licenses for the activity. However, the validity of state licenses as to AEC licensees is dubious, and it is even more doubtful, as a practical

47 E.g., California Regional Water Pollution Control Boards, CaL. Water Code $\$ \S 13000-$ 64, Cal. Health \& Safety Code $\$ \S 5410-75$; San Francisco Bay Area Pollution Control District, CaI. HeaITH \& SAFETy CODE $\$ \$ 24345-72$; and county air pollution control districts, CaI. Hearth \& SaFety Code $\$ \S 24198-349$. In Wisconsin, county boards have been authorized to regulate air pollution caused by radioactive materials, among other causes. Wrs. Srats. $\S 59.07(53)$, as amended, Wis. Laws of 1957 , c. 340 .

48 Note 32 supra.

49 AN INTERTM Report by the Southwestern Legal Foundation, The Feasibitity of a Southern Regional Compact on Nuclear Energy (1957). 
matter, that the states generally are either willing or ready to assume the responsibilities of a licensing system. The amendment to the Atomic Energy Act, proposed by the AEC, makes it clear that the states shall not exercise "licensing responsibilities" with respect to activities already licensed by the federal government..$^{50}$

However, there is no apparent objection to the requirement that all sources of radiation be registered with an agency of the state, particularly when it is made clear in the statute that registration does not imply approval of the activity. By such a law, the state may keep informed of the extent of radiation within its borders, both from AEC licensed sources and from more conventional sources such as X-ray machines and fluoroscopic shoe-fitting devices. While the AEC is compelled by law to give the states notice of licenses for commercial reactors ${ }^{51}$ and, in practice, gives notice of all reactor applications, ${ }^{\mathbf{5 2}}$ certain radioisotopes are distributed by general licenses-that is, not by a specific license to a named person. ${ }^{53}$

In Mlinois ${ }^{54}$ and North Dakota, ${ }^{55}$ statutes have been enacted requiring the registration of radiation sources, with certain exceptions. ${ }^{56}$ Connecticut, $^{57}$ South Dakota ${ }^{58}$ and Wyoming ${ }^{59}$ require registration incident to radiation protection laws. In New York, Pennsylvania and Texas, registration is required by admimistrative regulation. ${ }^{60}$ These statutes and regulations specify generally that registration does not imply approval of the activity. In contrast, the Delaware Board of Health in 1953 adopted a regulation which appears to be unique and of very doubtful validity. ${ }^{61}$ It requires that persons who might cause a hazard from the use of radioactive materials or maclines must first secure a permit from the Board of Health, and the

${ }^{50}$ AEC Proposed Amendment to Atomic Energy Act of 1954, $\$ 274$ (b) (1957).

51 Atomic Energy Act of 1954, §182b, 68 STAT. 954, as amended, 42 U.S.C. $\$ 2232$ (b) (Supp. TV 1956).

62 Price, Susatary of Proceedings, Conference of State Representatives on the AEC LicensLNG PrograMr 3-4 (1955).

53 General licenses are effective without the filing of applications with the AEC or the issuance of licensing documents to particular persons. 10 C.F.R. $\$ \$ 30.20,30.21$ (Supp. 1956). These licenses apply to byproduct material incorporated in certain devices or equipment, $i d$. $\S 30.71$, and certain quantities of byproduct material, $i d$. $\$ 30.72$.

54 Irr. REv. STAT. c. 1111/2, §§ 194-200 (1957).

55 N.D. Laws of 1957 , C. 185 (effective July 1, 1957).

56 E.g., certain quantities of radioactive materials not deemed harnful, timepieces, novelties, natural radioactive materials of an equivalent specific radioactivity not exceeding that of natural potassium.

57 Conn. Pub. Act No. 154, 1957.

58 Sess. Laws of S.D. 1957 , c. 122.

50 Sess. Laws of Wyo. 1953, c. 61, \$§ 1, 2, 3, as amended by Sess. Laws of Wyo. 1955, c. 153.

${ }^{60}$ See notes $14,15,17$, supra.

61 Delaware Regulations Governing Radiation Sources, adopted by Board of Health under authority of DEL. ANN. CoDE, title 16, chapter 1, §122(3) (k) (1953). 
board reserves the right to deny the permit. This "permit" seems indistinguishable from a hicense.

If a state requires registration before commencing operation, or the submission of any proposed change in operations, reserving the authority to disapprove such operations, this would seem to be the exercise of "licensing responsibilities," probably forbidden to the states as to AEC licenses. But could a state by a carefully drafted statute reserve the right of approval over a particular aspect of atomic energy operations, such as radioactive waste disposal, which is of great local importance and perhaps less national significance ${ }^{62}$ Another alternative of some usefulness might be the requirement that proposals be submitted sufficiently far in advance of operations that the state, while not reserving the power to stop the proposal, might bring its influence to bear upon the AEC. This would be analogous to the present AEC policy of supplying states with license applications before such licenses are acted on. The AEC has not hesitated to recognize the legitimate interest of the states in the health and safety consequences of atomic energy activity. In replying to applications for licenses to conduct disposal operations, representatives of the AEC have suggested to contractors that they discuss their proposed operations with interested state agencies.$^{63}$ State laws which would keep local officials informed of proposed operations and give them a voice in the decision-making process appear useful and valid.

\section{B. Inspection}

Effective health and safety protection requires, not only standards, but assurance that operations are conducted in accordance with the standards. This necessitates some form of inspection of radiation facilities and users of radioactive materials.

The AEC has actively encouraged the cooperation of the states in the inspection of its licensees. ${ }^{64}$ The basis for this policy is the scope and size of the inspection load, the traditional state regulation of health and safety pertaining to local industry, and the nationwide shortage of competent personnel. The attention of the AEC has been directed primarily to the some 4,000 users of radioisotopes and the growing number of users of source material. A state might be delegated inspection responsibilities for a group

62 See Dunlavey, Government Regulation of Atomic Indiustry, 105 U. PA. L. REv. 295, 344-47 (1957).

63 See letter from James W. Hitch of the AEC to a salvage company in San Pedro, Callfornia, proposing to dispose of wastes at sea. NEW DEVEIopMents TRANSFER BINDER, 19551957, CCH Atomac Energx L. Rep. If 7091.

64 See remarks of Curtis A. Nelson, Director of AEC Division of Inspection, AEC Presg Release, Feb. 2, 1957; see also Cguncte of State Governacents, The States and Atomic DeVELOPMENT 21-24 (1956). 
of licensees and supply copies of inspection reports and reports of noncompliance to the Commission for its information and appropriate action. The amendment to the Atomic Energy Act proposed by the AEC provides specifically for agreements with states and authorizes training of state employees. ${ }^{\circ 5}$ The Commision has been authorized by the act to use state or local agencies to perform "such functions on its behalf as may appear desirable." 68

In enacting radiation safety legislation, the states have generally authorized the inspection of radiation sources. ${ }^{67}$ State inspection programs may be, and should be, much broader than merely acting as an agent for the federal government with respect to AEC licensees. The states can also develop means of control over the many sources of radiation not under AEC jurisdiction, using the experience and training gained in cooperation with the AEC to great advantage. In order to avoid duplication and overlapping of functions, an effective inspection program requires some degree of state-wide coordination both to facilitate cooperation with the AEC and to insure cooperation among state agencies and local authorities. It may also be useful to integrate the inspection of radiation sources into conventional industrial and public safety inspection practices.

Since the sliortage of competent personnel is a major obstacle to adequate inspection, ${ }^{68}$ the states would be well advised to adopt whatever means are available to train personnel. whether by agreement with the federal government or otherwise. Certainly, in the absence of capable persons to administer radiation safety laws, the states can never, from a realistic standpoint, assume full responsibility over radiation activities.

\section{Sanctions}

An effective inspection program will indicate noncompliance with liealth and safety standards, but the final element of regulation is stopping hazardous activities and insuring, as far as possible, that they will not happen again. Pursuant to its licensing powers, the AEC has a substantial arsenal of weapons. The license may be revoked, and the AEC may recapture special nuclear material or enter upon and operate the facility prior to proceedings under the Administrative Procedure Act. ${ }^{69}$ The AEC may withdraw byproduct material from licensees who fail to observe safety stand-

65 AEC Proposed Amendment to Atomic Energy Act of 1954, \& 274(a) (1957).

${ }^{66}$ Atomic Energy Act of 1954, § 161f, 68 STAT. 949, as amended, 42 U.S.C. $\$ 2201$ (f) (Supp. IV 1956).

67 E.g., ILI. Crv. ADM. CoDE $\$ 55.32$ (1957).

68 Nationat Bureau of Standards Handboor No. 61, Regulation of Radiatton ExpoSURE BY LeGrSLATTVE MEANS 5 (1955).

${ }^{69}$ Atomic Energy Act of 1954, $\S 186,68$ STAT. 955, 42 U.S.C. $\$ 2236$ (Supp. IV 1956); 10 C.F.R. $\$ 2.203$ (Supp. 1956). 
ards. ${ }^{70}$ In a laboratory in Houston, Texas, pellets of radioactive material were broken while being uncanned, resulting in the contamination of the laboratory and exposure of two employees with the possible exposure of their homes, clothing and families. The AEC issued a temporary suspension order ordering the licensee not to resume operations pending a hearing in Washington on an order to show cause. ${ }^{71}$ Thereafter, the order was modified to permit operations not related to the incident, ${ }^{72}$ and the final result was that the licensee abandoned the division of its activities which had caused the incident rather than invest the capital necessary to correct the deficiencies. ${ }^{73}$ Similarly, notices of violations have been sent to industrial licensees resulting in prompt compliance. ${ }^{74}$ In addition, injunctive relief and criminal punishment are authorized for violation of the regulations. ${ }^{76}$

In the enforcement of conventional health and safety laws, a great many sanctions are normally available to state agencies. Where a license is required, administrative action to revoke or suspend the license may be initiated. Provisions of the state Industrial Safety Code are normally enforced in California by way of an order requiring corrective action and, if this is not complied with, criminal prosecution by the District Attorney. ${ }^{70}$ Some agencies have been delegated summary abatement power of health hazards with judicial review following. ${ }^{77}$ Usually injunctive relief may be obtained. ${ }^{78}$ With respect to radiation safety, states which have enacted safety regulations have usually clothed the responsible agency with authority to seek injunctive relief and defined violations as crimes. ${ }^{70}$

Under the AEC-proposed amendment to the 1954 Atomic Energy Act, states would be permitted to "enforce" their own safety standards. ${ }^{80}$ Would this permit a state agency to summarily stop operations of an AEC licensee, with an appeal permitted to the state courts? Assuming a state has the power to adopt standards, it would appear that the method of enforcement would lie with the state. However, it is easy to foresee considerable friction between federal and state officials should the states enter on vigorous en-

70 Atomic Energy Act of 1954, $\$ 81,68$ Srar. 935, 42 U.S.C. $\$ 2111$ (Supp. IV 1956).

71 AEC Press Release No. 1044, May 2, 1957; see 10 C.F.R. \$\$ 2.201, 2.202 (Supp. 1956).

72 AEC Press Release No. 1061, May 23, 1957.

73 See New Developarents Transfer Binder, 1955-1957, CCH Atomic Energy L. Rep. II 7115 .

74 Id. at $\mathbb{7} 7050$.

75 Atomic Energy Act of 1954, $\$$ 223, 230, 68 STat. 958, 959, 42 U.S.C. $\$ \S 2273,2280$ (Supp. IV 1956).

76 CAL. LABOR CODE $\$ \S 6500,6503,6414$.

77 E.g., see CAL. Heasth \& SAFETY Code $\$ \$ 28251-52$ (unsanitary bakeries); id. $\$ 26581$ (seizure and quarantine of adulterated food); see Skinner v. Coy, 13 Cal. 2d 407, 90 P.2d 296 (1939).

78 E.g., CAL. LABOR CODE $\$ 6508$ (industrial safety).

79 E.g., Ill., supra note 54; South Dakota, supra note 41.

80 AEC Proposed Amendment to Atomic Energy Act of 1954, § 274(b) (1957). 
forcement action by means of stop orders and injunctive relief. Suppose state and federal officials disagree over a supposed violation? There is no apparent reason why differences of opimion should not develop in this field as well as others. Certainly nothing would impair federal-state relations more than an injunctive action by the state which the AEC did not feel well founded. And, of course, nothing would better pose the constitutional and statutory issues heretofore discussed than a suit by the state to enjoin the operations of an AEC licensee.

While the states familiarize themselves with atomic energy, develop competent personnel and the experience and expertise necessary to formulate and enforce safety regulations, they might be well advised to rely generally on sanctions imposed by the AEC. There is at present a strong feeling of cooperation on both sides which should not be impaired. Furthermore, the AEC sanctions are perhaps speedier and less complicated than the sometimes slow routine of judicial process.

\section{CONCLUSTON}

In the few years since the passage of the Atomic Energy Act of 1954, state governments have received some criticism for their failure, generally, to attempt to deal with the problems growing out of the atomic era. ${ }^{81}$ Due probably in part to this stimulus, the pace of state action has accelerated since 1954. A rough survey in 1957 revealed that at least twenty-two states enacted some type of legislation dealing with atomic energy in that year. ${ }^{82}$

A quarter of our states have now enacted the New England Model Act in substance. ${ }^{83}$ However, this act only sets up the framework for adequate state action. What follows must be continued study and planning, together with substantive regulation of those areas of activity peculiarly important to local interests. The New England Act does establish a method for insuring uniformity and consistency in the control of atomic energy as among state agencies and even ainong different levels of state government, as well as establishing a framework for state-federal relations and multistate action. There must be some centralization of state authority for effective use of the information obtained by requiring the registration of radiation sources, for insuring the maximum degree of cooperation in the performance of federal and state inspection functions, and for the exercise of the most useful sanctions to be employed in particular instances.

If the Atomic Energy Act of 1954 is a "transitional law for a transi-

81 See, e.g., note 31 suppra; remarks of Senator Clinton Anderson, CouncI of Stare Governatents, Conference on the States and Atoartc Development 16-22 (May 10-11, 1957).

82 For a summary, see Aromic Industriat Fordu, Inc., State Activities in Atonic ENERGY (Feb. 1, 1957).

83 See text at notes 34 to 39 supra. 
tional period, ${ }^{284}$ presumably the states must one day shoulder full responsibility for health and safety in the atomic energy industry as well as in other more conventional industries. If the states are to be prepared for this responsibility, they must commence at least to organize state government to handle these problems and to accumulate the competent personnel who are necessary for the administration of any effective health and safety program. 


\section{California Law Review}

MIEAIBER FATIONAL AND WESTERN CONFERENCES OF IAW REVIEWS

Published Five Times Yearly by Students of the School of Law of the

University of California, Berkeley, California. Indexed in Index to Legal Periodicals and Public Affairs Information Service.

\section{BOARD OF EDITORS \\ ARthur O. ARMSTRONG, JR. Editor}

\section{Charles A. Mutuer}

Assistant Editor

Davm D. Warksey

Managing Editor

JoHT E. BreckeNRIDGE Marcotar S. Burnstern Mrtes A. Cobb

Georg Geiger

Paul W. Harthofe, JR.

\author{
Bruce M. Cowant \\ Article Editor
}

EdMund L. Regacta

Book Review Editor

Associate Editors

WIITTAM L. HugHES

HaRold C. NaCHTrIeB

Sherdon C. St. Cratr

Jan S. Stevens

HOWARD M. WETSER

Anne Hosman

General Secretary

\section{Contributors}

Jomar L. Cardoza

LEE H. CIFF

E. MHES HaRVEY

George A. Matroch
Paut Robeñs

E. Robert WaLtact Stanton G. Ware RICHARD A. WIISON 